\title{
Industrial residues as substrate components for the production of Ilex paraguariensis seedlings
}

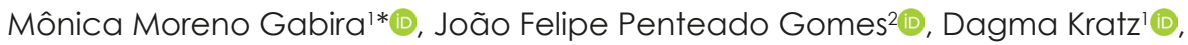 \\ Ivar Wendling ${ }^{3} \odot$, Carlos André Stuepp ${ }^{2}(0)$ \\ 'Federal University of Paraná, Curitiba, Brazil \\ ${ }^{2}$ State University of Ponta Grossa, Ponta Grossa, Brazil \\ ${ }^{3}$ Embrapa Florestas, Colombo, Brazil \\ *Corresponding author, e-mail: ag.antoniogabriel@gmail.com
}

\begin{abstract}
Ilex paraguariensis is an important forest species in Brazil. Recently, the development of new products has increased seedlings demand and consequently, the interest in new products to use as substrates like residues from industries. We aimed to evaluate the viability of using industrial residues as substrates to produce yerba mate seedlings. We formulated thirteen substrates with coconut fiber, carbonized and decomposed yerba mate industrial residues in different ratios, which were compared to two commercial substrates, in a completely randomized design. The stratified seeds were placed in $110 \mathrm{~cm}^{3}$ tubes filled with the substrates. Plants were kept in a greenhouse for 135 days, shade house (70\%) for 30 days, and rustification area in full sunlight for 15 days, under fertigation after 30 days of sowing. We evaluated montlhy the survival, height, and stem diameter, and at the end of the production period, we evaluated shoot and root dry mass. From the data obtained, we calculated the total dry mass and 'Dickson quality index'. The substrates formulated with coconut fiber and decomposed yerba mate industrial residue can be used to produce yerba mate seedlings, but it depends on the ratio of the substrate components. Substrates with higher total porosity and microporosity provided seedlings with biometric characteristics similar to those produced in commercial substrates. The carbonized yerba mate residue reduced seedling growth when used in a percentage equal to or higher than $50 \%$ in the substrate.
\end{abstract}

Keywords: forest nurseries, seedling production, seedling quality, yerba mate

\section{Introduction}

Yerba mate (Ilex paraguariensis A.St.-Hil.) is a species native to South America, traditionally consumed as chimarrão, tereré, and tea, but is also widely used to produce dyes, ice creams, perfumes, deodorants and medicines (Dartora et al., 2013). In recent decades, the extraction of yerba mate leaves from native areas has been replaced by intensive cultivation of the species. The increase in planted areas with yerba mate has lead to an increase in the demand for seedlings and it encouraged the development of studies focusing on the best practices and materials to establish high-quality crops.

The establishment of yerba mate plantations, as well as other arboreal species, is closely related to seedling quality, which directly depends on production factors such as substrate, irrigation, and seed and container quality. Substrate stands out among these factors, as it is a porous solid medium that supports the plant and must present physical and chemical characteristics that provide quality root system and shoot formation (Trigueiro \& Guerrini, 2014).

An efficient substrate must contain the physical, chemical, and biological characteristics for plant development in a restricted environment, as well as meet the practical requirements of the production system in which it is inserted (Barrett et al., 2016). Substrate quality determines the management of other factors, such as irrigation and nutrition, and also influences the seedling production cycle in a variety of ways (Fermino et al., 2018). Some characteristics that affect plant development are the physical properties related to material origin, production method, and component ratio (Wendling et al., 2007). To ensure all the necessary characteristics to plant species, two or more materials must be used in a substrate, which should be formulated to provide the appropriate aeration and water availability conditions. 
Commercial substrates are generally peatbased, which is a lightweight, easily obtainable organic material with high water retention capacity; however, peat extraction generates environmental impacts. In this context, the use of alternative substrates has become important due to their costs and characteristics, emphasizing materials from agricultural, industrial and urban waste, which generate less environmental impacts (Raviv, 2013). Many organic residues are used as substrate components; however, these residues are not found in all regions of Brazil, increasing acquisition costs in locations far from their sources (Kratz et al., 2017). Thus, studies focusing on using different organic residues as substrate components are essential to meet this demand in the most diverse seedling producing regions.

The industrial process of yerba mate involves a severe thermal treatment of leaves and twigs, a drying stage, and grinding, which generates residue (Holowaty et al., 2016; Fernandes et al., 2016). The residue generated from this process requires adequate disposal since it is not currently recycled or exploited as a bio-resource. We considered the hypothesis that the treatment given to the residues can change its characteristics and that industria residue can be used as substrates component. Thus, we aimed to evaluate the viability of using decomposed and carbonized yerba mate as substrate components for the production of yerba mate seedlings, as well as to analyze their physical properties.

\section{Material and Methods}

The experiment was conducted between December 2017 and April 2018, at the Bitumirim Ind. Company of Yerba Mate Ltda., in Ivaí, PR, Brazil, at the coordinates $25^{\circ} 1$ '8.64'S and 50 $49^{\prime} 13.29$ "W and altitude of $750 \mathrm{~m}$. The climate of the region is Cfa type, characterized as humid subtropical, with average temperature of the coldest month less than $18^{\circ} \mathrm{C}$ and average temperature of the warmest month above $22{ }^{\circ} \mathrm{C}$, presenting hot summers, infrequent frosts and tendency of rainfall concentration in the summer months, however, with no defined dry season (Alvares et al., 2013). The average annual rainfall is around $1,500 \mathrm{~mm}$ and water surplus ranges from 500 to $800 \mathrm{~mm}$.

The seeds came from a clonal orchard of seeds belonging to the Bitumirim S.A. Company, submitted to a stratification process similar to that described by Cuquel (1994) and Fowler (2000), until they reached sowing point in the flowerbed. Seeds with a maximum root axis of $1.5 \mathrm{~mm}$ were selected and placed in a Styrofoam box with water and then planted in $110 \mathrm{~cm}^{3}$ tubes filled with the substrates described above. The substrates used to produce the yerba mate seedlings were prepared from waste of the yerba mate industry and compared to two commercially available substrates (Agrinobre ${ }^{\circledR}$ and Carolina Soil ${ }^{\circledR}$ ) (Table 1). The experiment was carried out according to a completely randomized design, in a split-plot model with four replicates of 20 seedlings per experimental unit.

Table 1. Description of the substrate formulations used to produce seedlings of llex paraguariensis.

\begin{tabular}{|c|c|c|c|c|c|}
\hline \multirow{2}{*}{ Substrate } & \multicolumn{5}{|c|}{ Material (\%) } \\
\hline & CS1 & CS2 & $\mathrm{CF}$ & DYM & CYM \\
\hline CS1 & 100.0 & & & & \\
\hline CS2 & & 100.0 & & & \\
\hline$C F+D Y M+C Y M(1: 1: 1 \mathrm{v}: \mathrm{v}: \mathrm{v})$ & & & 33.3 & 33.3 & 33.3 \\
\hline CF+DYM+CYM (2:1:1 v:v:v) & & & 50.0 & 25.0 & 25.0 \\
\hline$C F+D Y M+C Y M(1: 2: 1 \mathrm{v}: \mathrm{v}: \mathrm{v})$ & & & 25.0 & 50.0 & 25.0 \\
\hline CF+DYM+CYM (1:1:2 v:v:v) & & & 25.0 & 25.0 & 50.0 \\
\hline CF+DYM $(1: 1 \mathrm{v}: \mathrm{v})$ & & & 50.0 & 50.0 & \\
\hline CF+DYM (2:1 v:v) & & & 66.6 & 33.3 & \\
\hline CF+DYM (1:2 v:v) & & & 33.3 & 66.6 & \\
\hline DYM+CYM (1:1 v:v) & & & & 50.0 & 50.0 \\
\hline DYM+CYM (2:1 v:v) & & & & 66.6 & 33.3 \\
\hline DYM+CYM (1:2 v:v) & & & & 33.3 & 66.6 \\
\hline CF+CYM (1:1 v:v) & & & 50.0 & & 50.0 \\
\hline$C F+C Y M(2: 1 \vee: v)$ & & & 66.6 & & 33.3 \\
\hline$C F+C Y M(1: 2 \mathrm{v}: \mathrm{v})$ & & & 33.3 & & 66.6 \\
\hline
\end{tabular}

The decomposed yerba mate residue (DYM) was prepared by depositing the dry material in an open, uncontrolled area where it was left to decompose for one year like traditional yerba mate industries do to properly allocate this material. The carbonized yerba mate residue (CYM) was prepared similarly to charcoal, in which the material was burnt slowly with little available oxygen for total carbonization to occur. Both were produced by the Bitumirim Company, using residues from the yerba mate industry. The substrates were submitted to physical and chemical analysis according to the methodology proposed by Brasil (2007), from which the apparent density, water retention capacity at $10 \mathrm{~cm}$ of tension or microporosity, macroporosity, total porosity, electrical conductivity, and pH were measured.

After planting, tubes were kept in a greenhouse with $50 \%$ shading and nebulization irrigation with an interval of 1 hour, duration of 60 seconds and flow rate of $28.0 \mathrm{~L} \mathrm{hour}^{-1}$; to keep the surface of the substrate wet. After 30 days, plants were irrigated every 3 hours. At 105 days the plants were transferred to the shade house (70\% shading) with four daily irrigations via micro-sprinkler of 10 minutes and flow rate of $144 \mathrm{~L} \mathrm{hour}^{-1}$, where they remained for 30 days. Afterwards, plants were moved to the rustification area in full sunlight for 15 days, receiving 4 
irrigations of 30 minutes with flow rate of $97 \mathrm{~L}$ hour-1 every day.

Fertigation began at 30 days after sowing 10.15 $\mathrm{g} \mathrm{L}^{-1}$ Ammonium sulfate, $2.3 \mathrm{~g} \mathrm{~L}^{-1}$ of Yoorin MG, $1.6 \mathrm{~g} \mathrm{~L}^{-1}$ potassium chloride and $0.25 \mathrm{~g} \mathrm{~L}^{-1}$ of FTE BR 10 [7 \% Zn, 4 \% Fe, 4 \% Mn, 0.1 \% Mo, 2.5 \% B, 0.8 \% Cu]), performed every seven days ( $4 \mathrm{ml}^{\text {seedling }}{ }^{-1}$ ) up to 105 days, when seedlings were transferred to the shadow house. There, growth fertilization was applied $\left(4 \mathrm{~g} \mathrm{~L}^{-1}\right.$ of urea, $3 \mathrm{~g} \mathrm{~L}^{-1}$ de Yoorin MG, $3 \mathrm{~g} \mathrm{~L}^{-1}$ of potassium chloride, $0.25 \mathrm{~g} \mathrm{~L}^{-1}$ of FTE BR 10 ) every seven days ( $4 \mathrm{ml}$ seedling ${ }^{-1}$ ) up to 135 days, when rustification began $\left(4 \mathrm{~g} \mathrm{~L}^{-1}\right.$ of ammonium sulfate, $10 \mathrm{~g} \mathrm{~L}^{-1}$ of Yoorin MG, $4 \mathrm{~g} \mathrm{~L}^{-1}$ of potassium chloride, $1 \mathrm{~g} \mathrm{~L}^{-1}$ of FTE BR 10), every seven days ( $\left.4 \mathrm{ml}^{\text {seedling }}{ }^{-1}\right)$ until 150 days.

Survival at 30, 60, 90, 120 and 150 days after sowing, height $(\mathrm{H})$ (using a ruler) at $60,90,120$ and 150 days after sowing, stem diameter (SD) (using a digital caliper) at 90, 120 and 150 days after sowing were measured in all plants. At 150 days, five representative plants per sampling unit were selected to evaluate shoot dry mass, root dry mass and total dry mass, by drying in an oven for 48 hours at $65^{\circ} \mathrm{C}$ and weighing plant parts on an analytical scale with 0.001 grams precision. Furthermore, the ease in which seedlings were removed from tubes and root aggregation were evaluated according to the methodology described by Wendling et al. (2007). From this data, the morphological index of the relationship between height and stem diameter (H/SD) at 90, 120 and 150 days and the Dickson quality index (DQI) were calculated, determined by the following formula:

Where,

$$
D Q I=\frac{T D M}{H / S D+S D M / R D M}
$$

TDM - Total Dry Mass (g);

RDM - Root Dry mass (g);

SDM - Shoot Dry Mass (g);

$\mathrm{H} / \mathrm{SD}$ - Ratio index between shoot height $(\mathrm{H})$ and stem diameter (SD).

To classify the 15 substrates, they were ordered according to their technical efficiency for each variable measured, with weight 13 assigned to the most efficient substrate and decreasing values for the others. The definition of the relative importance of each variable for seedling quality was based on studies developed by Gomes et al. (2002). The weighted sum or technical efficiency was obtained according to the following equation (Kratz et al., 2016):

$E F=(T D M * 0.40)+(S D M * 0.25)+R D M+(S D * 0.10)+(H * 0.05)+(A G * 0.05)$
Where,

TDM - Total Dry Mass (g);

RDM - Root Dry mass (g);

SDM - Shoot dry Mass (g);

H/SD - Relationship index between shoot height (H) and stem diameter (SD);

AG - Aggregation of roots to substrate.

Data of the biometric characteristics of the seedlings was subjected to the Bartlett test $(p<0.05)$ to verify the homogeneity condition of the variances and then the analysis of variance (ANOVA) $(p<0.05)$, comparing averages by the Scott-Knott test $(p<0.05)$. The data was also subjected to Pearson correlation at $5 \%$ significance, between substrate and the seedling characteristics. We conducted all the statistical analyses with R software (R Core Team, 2019).

\section{Results and Discussion}

Density, macroporosity, microporosity and total porosity differ between substrates according to the ratio of the materials used. Substrates with a proportion higher than 50\% DYM (decomposed yerba mate) presented higher density values, while substrates composed of CF (coconut fiber) and CYM (carbonized yerba mate) showed the lowest values for this characteristic (Table 2).

Substrates with high densities have reduced drainage and aeration, providing a poor environment for root system development (Trigueiro \& Guerrini, 2014). As density values decreased, total porosity values increased, varying between the substrate compositions and the percentages of macro and micropores. Such characteristics are important as they determine the distribution of air, water and solid particles in substrates (Pascual, 2018).

Despite the differences in physical and chemical characteristics, all materials used in this experiment could potentially be used as substrate components to produce seedlings of yerba mate, as all of them fitted in parameters used by other authors as adequate for seedlings production (Trigueiro \& Guerrini, 2014; Kratz et al., 2017; Pascual, 2018). However, it is important to consider the ratio of the materials used as substrates components because different particle sizes and shapes of the substrate components may interfere with the arrangement of the mixtures and, consequently, in their physical characteristics (Fermino et al., 2018). Therefore, the decomposition and carbonization processes directly influenced the physical and chemical characteristics of the yerba mate residue and, consequently, altered the substrates in which these residues were used.

Adding DYM to the substrate composition 
increases its density and, when in mixes with CF, microporosity also increases. Simões et al. (2012) and Kratz et al. (2013) cite coconut fiber as a material that, although light, increases the microporosity of substrates due to the presence of internal pores, allowing seedling development even under conditions of low water availability. On the other hand, mixtures of DYM and CYM result in materials with low microporosity and total porosity. These values are important since the physical characteristics of a substrate determine the frequency and intensity of water and nutrient application during the seedling production process (Simões et al., 2012).

Although there were differences between treatments, the electrical conductivity remained within the standards required for plant substrates, i.e., below 1.0 $\mathrm{mS} \mathrm{cm}^{-1}$ (Gonçalves et al., 2000). According to Pascual et al. (2018), electrical conductivity is related to the total amount of soluble salts in the saturated extract of the substrate, expressed by the solution's ability to conduct electrical current. High electrical conductivity values can negatively affect plant root growth, significantly influencing seedling quality. The substrates with the CYM component, regardless of the ratio, had lower $\mathrm{pH}$ values; it is a common characteristic of substrates with carbonized components (Kratz et al., 2017).

Seedling survival showed no influence by substrates in all production phases, remaining above $95 \%$ in all assessments performed. These values suggest adequate conditions for yerba mate seedlings in all substrates tested, despite differences observed in the physical analysis. In turn, the height and diameter showed differences between the treatments from the first evaluation (Table 3).

Table 3. Height $(\mathrm{H})$ at $60,90,120$, and 150 days after sowing, and stem diameter (SD) at 90,120 , and 150 days after sowing of llex paraguariensis seedlings produced in different substrates.

\begin{tabular}{|c|c|c|c|c|c|c|c|}
\hline \multirow{2}{*}{ Substrate } & $\mathrm{H} 60$ & $\mathrm{H} 90$ & $\mathrm{H} 120$ & $\mathrm{H} 150$ & SD90 & SD120 & SD150 \\
\hline & \multicolumn{4}{|c|}{$\mathrm{cm}$} & \multicolumn{3}{|c|}{$\mathrm{mm}$} \\
\hline CS1 & $2.5 a$ & $5.4 \mathrm{a}$ & $14.8 a$ & $22.8 a$ & $1.98 \mathrm{a}$ & $2.84 a$ & $4.85 \mathrm{a}$ \\
\hline CS2 & $1.9 \mathrm{~b}$ & $3.9 \mathrm{~b}$ & $11.0 \mathrm{~b}$ & $19.8 \mathrm{a}$ & $1.61 \mathrm{~b}$ & $2.39 \mathrm{~b}$ & $4.72 \mathrm{a}$ \\
\hline CF+DYM+CYM $(1: 1: 1)$ & $2.0 \mathrm{~b}$ & $4.1 \mathrm{a}$ & $12.2 \mathrm{~b}$ & $18.2 \mathrm{a}$ & $1.69 \mathrm{a}$ & $2.48 a$ & $4.45 a$ \\
\hline CF+DYM+CYM (2:1:1) & $2.0 \mathrm{~b}$ & $3.7 \mathrm{~b}$ & $11.1 \mathrm{~b}$ & $17.5 \mathrm{a}$ & $1.57 \mathrm{~b}$ & $2.43 b$ & $4.50 \mathrm{a}$ \\
\hline CF+DYM+CYM (1:2:1) & $2.2 a$ & $4.4 \mathrm{a}$ & $11.6 \mathrm{~b}$ & $20.0 a$ & $1.68 \mathrm{a}$ & $2.55 a$ & $4.40 \mathrm{a}$ \\
\hline CF+DYM+CYM (1:1:2) & $1.9 \mathrm{~b}$ & $3.4 \mathrm{~b}$ & $8.9 \mathrm{c}$ & $17.9 \mathrm{a}$ & $1.53 \mathrm{~b}$ & $2.28 \mathrm{~b}$ & $4.20 \mathrm{~b}$ \\
\hline CF+DYM $(1: 1)$ & $2.2 \mathrm{a}$ & $4.3 a$ & $12.3 \mathrm{~b}$ & $20.0 a$ & $1.74 \mathrm{a}$ & $2.68 a$ & $4.65 \mathrm{a}$ \\
\hline CF+DYM $(2: 1)$ & $2.2 \mathrm{a}$ & $4.8 \mathrm{a}$ & $14.2 \mathrm{a}$ & $21.3 \mathrm{a}$ & $1.82 \mathrm{a}$ & $2.68 a$ & $5.03 a$ \\
\hline CF+DYM (1:2) & $2.2 \mathrm{a}$ & $4.3 a$ & $12.7 \mathrm{~b}$ & $20.4 a$ & $1.74 \mathrm{a}$ & $2.59 \mathrm{a}$ & $4.73 a$ \\
\hline DYM+CYM (1:1) & $2.2 a$ & $3.3 b$ & $8.1 \mathrm{C}$ & $14.6 a$ & $1.52 \mathrm{~b}$ & $2.31 \mathrm{~b}$ & $3.54 \mathrm{~b}$ \\
\hline DYM+CYM (2:1) & $2.0 \mathrm{~b}$ & $3.6 \mathrm{~b}$ & $8.4 \mathrm{c}$ & $12.7 \mathrm{~b}$ & $1.59 \mathrm{~b}$ & $2.34 \mathrm{~b}$ & $3.91 \mathrm{~b}$ \\
\hline DYM+CYM (1:2) & $1.8 \mathrm{~b}$ & $3.1 \mathrm{~b}$ & $6.5 c$ & $11.4 \mathrm{~b}$ & $1.42 \mathrm{~b}$ & $2.12 b$ & $3.83 \mathrm{~b}$ \\
\hline$C F+C Y M(1: 1)$ & $1.7 \mathrm{~b}$ & $3.2 \mathrm{~b}$ & $9.2 \mathrm{C}$ & $11.9 \mathrm{~b}$ & $1.52 \mathrm{~b}$ & $2.31 \mathrm{~b}$ & $4.05 \mathrm{~b}$ \\
\hline $\mathrm{CF}+\mathrm{CYM}(2: 1)$ & $1.9 \mathrm{~b}$ & $3.7 \mathrm{~b}$ & $9.4 \mathrm{c}$ & $15.4 \mathrm{~b}$ & $1.55 \mathrm{~b}$ & $2.32 \mathrm{~b}$ & $4.37 \mathrm{a}$ \\
\hline$C F+C Y M(1: 2)$ & $1.9 \mathrm{~b}$ & $3.3 \mathrm{~b}$ & $7.3 c$ & $14.4 \mathrm{~b}$ & $1.47 \mathrm{~b}$ & $2.18 \mathrm{~b}$ & $4.16 \mathrm{~b}$ \\
\hline CV (\%) & 9.8 & 16.6 & 14.3 & 14.4 & 11.71 & 7.35 & 9.77 \\
\hline
\end{tabular}

Plant height and diameter was influenced by substrates in all phases of seedling production. In the first 60 days after sowing, seedlings produced in the CS 1 substrate presented the highest height and diameter averages, similarly to those produced in substrates with different proportions of $\mathrm{CF}+\mathrm{DYM}+\mathrm{CYM}$ and $\mathrm{CF}$ + DYM. However, this behavior changed in subsequent measurements and, at the end of the experiment, only seedlings produced in the DYM + CYM (2:1 and 1:2) and CF + CYM (1:1) substrates had lower average heights than seedlings produced in commercial substrates. Regarding diameter, the seedlings produced in the different DYM + CYM substrates presented lower averages than seedlings in the treatments with commercial substrates.

For the dry mass of plants, distinct behaviors were noticed for shoots and roots (Table 4). The shoot dry mass was less influenced by the treatments and seedlings of only three substrates presented a lower average than seedlings produced in the commercial substrates: DYM+CYM (1:1 and 1:2) and CF+CYM (1:1). The root dry mass showed higher averages only for seedlings produced in the CS1, CF+DYM+CYM (1:2:1) and CF+DYM (2:1) substrates, differing from seedlings produced in other substrates. These values influence the Dickson Quality Index (DQI), as demonstrated by Binotto et al. (2010) and in this study DQI values showed differences between treatments similar to shoot dry mass. DQI values can vary between 0.2 and 2.5, as observed by Gomes et al. (2002), Silva et al. (2012) Kratz et al. (2013) and Dutra et al. (2018) for other species, indicating that the seedlings obtained 
in this study are within the quality standards common to forest seedlings. However, it is necessary to pay attention to the fact that these values should be determined for each plant species, requiring further research focused on yerba mate seedlings.

Table 4. Height/diameter ratio (H/D), shoot dry mass (SDM), root dry mass (RDM), total dry mass (TDM), Dickson Quality Index (DQI), Tube withdrawal ease (TWE), substrate aggregation (AG) and technical efficiency (TE) in llex paraguariensis seedlings produced in different substrates at 150 days.

\begin{tabular}{|c|c|c|c|c|c|c|c|c|}
\hline Substrate & $H / D$ & SDM & $\begin{array}{c}\text { RDM } \\
\text { (g) }\end{array}$ & TDM & DQI & TWE & AG & TE \\
\hline CS1 & $4.77 a$ & $14.45 \mathrm{a}$ & $21.54 \mathrm{a}$ & $35.99 a$ & $8.44 a$ & $9.75 \mathrm{a}$ & $9.45 a$ & $18.82 a$ \\
\hline CS2 & $4.19 \mathrm{a}$ & $13.15 a$ & $13.73 a$ & $26.88 \mathrm{~b}$ & $7.48 \mathrm{a}$ & $9.90 \mathrm{a}$ & $9.00 \mathrm{a}$ & $14.29 \mathrm{~b}$ \\
\hline CF+DYM+CYM $(1: 1: 1)$ & $4.11 \mathrm{a}$ & $11.86 a$ & $10.09 \mathrm{~b}$ & $21.96 \mathrm{~b}$ & $6.83 a$ & $8.65 \mathrm{~b}$ & $6.04 \mathrm{~b}$ & $11.87 \mathrm{~b}$ \\
\hline CF+DYM+CYM $(2: 1: 1)$ & $3.90 \mathrm{a}$ & $13.35 a$ & $12.11 \mathrm{~b}$ & $25.46 \mathrm{~b}$ & $8.05 \mathrm{a}$ & $8.50 \mathrm{~b}$ & $8.35 a$ & $13.50 \mathrm{~b}$ \\
\hline CF+DYM+CYM $(1: 2: 1)$ & $4.53 a$ & $12.45 a$ & $17.80 \mathrm{a}$ & $30.25 a$ & $7.51 \mathrm{a}$ & $8.70 \mathrm{~b}$ & $7.90 a$ & $15.90 a$ \\
\hline$C F+D Y M+C Y M(1: 1: 2)$ & $4.27 \mathrm{a}$ & $22.63 a$ & $8.48 \mathrm{~b}$ & $20.11 \mathrm{c}$ & $6.54 \mathrm{a}$ & $9.05 a$ & $7.25 \mathrm{~b}$ & $11.01 \mathrm{C}$ \\
\hline CF+DYM $(1: 1)$ & $4.32 \mathrm{a}$ & $12.83 a$ & $11.77 \mathrm{~b}$ & $24.60 \mathrm{~b}$ & $6.85 a$ & $8.75 \mathrm{~b}$ & $8.80 a$ & $13.20 \mathrm{~b}$ \\
\hline CF+DYM (2:1) & $4.23 a$ & $14.16 \mathrm{a}$ & $17.56 \mathrm{a}$ & $31.72 \mathrm{a}$ & $8.40 \mathrm{a}$ & $9.20 \mathrm{a}$ & $9.65 a$ & $16.72 a$ \\
\hline CF+DYM (1:2) & $4.36 a$ & $11.13 a$ & $11.75 \mathrm{~b}$ & $22.88 \mathrm{~b}$ & $6.54 a$ & $9.20 \mathrm{a}$ & $8.5 \mathrm{a}$ & $12.58 \mathrm{~b}$ \\
\hline DYM+CYM (1:1) & $4.18 a$ & $5.96 \mathrm{~b}$ & $5.70 \mathrm{~b}$ & $11.67 \mathrm{~d}$ & $4.61 \mathrm{a}$ & $8.00 \mathrm{~b}$ & $5.07 \mathrm{C}$ & $7.04 \mathrm{~d}$ \\
\hline DYM+CYM (2:1) & $3.28 \mathrm{~b}$ & $8.91 \mathrm{~b}$ & $4.95 \mathrm{~b}$ & $13.86 d$ & $6.26 \mathrm{a}$ & $8.20 \mathrm{~b}$ & $6.15 \mathrm{C}$ & $7.85 \mathrm{~d}$ \\
\hline DYM+CYM (1:2) & $2.98 \mathrm{~b}$ & $8.19 \mathrm{~b}$ & $3.97 \mathrm{~b}$ & $12.15 \mathrm{~d}$ & $7.17 \mathrm{a}$ & $8.40 \mathrm{~b}$ & $5.29 \mathrm{C}$ & $7.26 \mathrm{~d}$ \\
\hline$C F+C Y M(1: 1)$ & $2.99 \mathrm{~b}$ & 8.22 b & $10.13 b$ & $18.35 \mathrm{C}$ & $7.49 \mathrm{a}$ & $8.60 \mathrm{~b}$ & $7.95 a$ & $10.09 \mathrm{C}$ \\
\hline CF+CYM (2:1) & $3.57 \mathrm{~b}$ & $10.35 \mathrm{~b}$ & $13.70 a$ & $24.05 \mathrm{~b}$ & $7.99 \mathrm{a}$ & $7.95 \mathrm{~b}$ & $8.90 a$ & $12.93 \mathrm{~b}$ \\
\hline$C F+C Y M(1: 2)$ & $3.47 \mathrm{~b}$ & 8.96 b & $7.96 \mathrm{~b}$ & $16.92 \mathrm{C}$ & $6.13 \mathrm{a}$ & $8.45 \mathrm{~b}$ & $5.70 \mathrm{c}$ & $9.40 \mathrm{c}$ \\
\hline CV (\%) & 14.81 & 22.05 & 30.17 & 19.69 & 21.32 & 6.33 & 11.39 & 17.17 \\
\hline
\end{tabular}

Ease of removal from the tube, substrate the packaging can expose roots to dryness (Wendling \& aggregation and technical efficiency are closely related and presented lower averages for plants produced in substrates composed of DYM + CYM, in all ratios tested. Root system aggregation is very important for plant survival after field planting, as clod rupture when removed from Delgado, 2008). This variable was highly correlated with microporosity, total porosity and $\mathrm{pH}$ of the substrates, highlighting the importance of these characteristics for deciding how to use alternative substrates to produce yerba mate seedlings (Table 5).

Table 5. Correlation coefficients between physical characteristics of substrates (density, microporosity, macroporosity, total porosity- TP), Survival (S), stem diameter (SD), height $(H)$, height/diameter ratio (H/D), aggregation of roots to substrate (AG), tube withdrawal ease (TWE), shoot dry mass (SDM), root dry mass (RDM), total dry mass (TDM), dry mass ratio (SDM/RDM), Dickson Quality Index (DQI) and technical efficiency (TE) of llex paraguariensis seedlings produced in different substrates at 150 days.

\begin{tabular}{|c|c|c|c|c|c|c|}
\hline & Density & Micro & Macro & PT & CE & $\mathrm{pH}$ \\
\hline$S$ & $0.13^{n s}$ & $-0.02^{\mathrm{ns}}$ & $-0.00^{n s}$ & $-0.03^{n s}$ & $0.23^{n s}$ & $-0.14^{\mathrm{ns}}$ \\
\hline$S D$ & $-0.13^{\text {ns }}$ & $0.26^{\mathrm{ns}}$ & $0.00^{n s}$ & $0.40 *$ & $0.21^{\mathrm{ns}}$ & $-0.71^{* *}$ \\
\hline $\mathrm{H}$ & $0.05^{\mathrm{ns}}$ & $0.16^{\mathrm{ns}}$ & 0.22 ns & $0.52 * *$ & $0.16^{\mathrm{ns}}$ & $-0.65^{* *}$ \\
\hline$H / D$ & $0.13^{n s}$ & $0.06^{\text {ns }}$ & $0.27^{\mathrm{ns}}$ & $0.45^{* *}$ & $0.15^{\mathrm{ns}}$ & $-0.47^{* *}$ \\
\hline$A G$ & -0.27 ns & $0.54^{* *}$ & $-0.18^{\mathrm{ns}}$ & $0.58 * *$ & $0.06^{\mathrm{ns}}$ & $-0.77^{* *}$ \\
\hline TWE & $-0.15^{\text {ns }}$ & $0.15^{\mathrm{ns}}$ & $-0.13^{\mathrm{ns}}$ & $0.06^{\mathrm{ns}}$ & $-0.08^{\text {ns }}$ & $-0.61^{* *}$ \\
\hline SDM & $-0.06^{\text {ns }}$ & $0.22^{\mathrm{ns}}$ & $0.06^{\mathrm{ns}}$ & $0.43 * *$ & $0.14^{\mathrm{ns}}$ & $-0.67^{* *}$ \\
\hline RDM & -0.19 ns & 0.29 ns & $0.02^{\mathrm{ns}}$ & $0.43^{* *}$ & $-0.06^{\text {ns }}$ & $-0.58 * *$ \\
\hline TDM & -0.18 ns & $0.32 *$ & $0.044^{\mathrm{ns}}$ & $0.55 * *$ & $0.01 \mathrm{~ns}$ & $-0.75^{* *}$ \\
\hline SDM/RDM & $0.14^{\mathrm{ns}}$ & $-0.23^{n s}$ & $0.07^{\mathrm{ns}}$ & $-0.26^{\mathrm{ns}}$ & $0.011^{n s}$ & $0.38 *$ \\
\hline DQI & $-0.32 *$ & $0.19 \mathrm{~ns}$ & $-006^{n s}$ & $0.21 \mathrm{~ns}$ & $-0.12^{\mathrm{ns}}$ & $-0.34 *$ \\
\hline $\mathrm{TE}$ & -0.17 ns & $0.32 *$ & $0.05^{\mathrm{ns}}$ & $0.56^{* *}$ & $0.011^{n s}$ & $-0.75 * *$ \\
\hline
\end{tabular}

In this experiment, seedling growth occurred at different rates between treatments. However, at the end of the production period, only seedlings produced in substrates with lower microporosity and total porosity values presented lower biometric characteristics than seedlings produced in commercial substrates. There is a close connection between porosity of the substrate and air and water availability for plant root systems (Suguino et al., 2013). Silva et al. (2012), in an experiment with Eucalyptus seedlings, observed that substrates with high total porosity promoted higher quality of the root system and, consequently, better shoot and root dry mass. 
On the other hand, the $\mathrm{pH}$ of substrates was negatively correlated to all the parameters evaluated for the seedlings, except survival. Yerba mate naturally develops in acidic soils (Reissmann et al., 1999; Barbosa et al., 2018), indicating the importance of this aspect for seedling production. Substrate $\mathrm{pH}$ directly affects nutrient mobility and availability (Pascual et al., 2018) and, when outside the ideal range for a species, can be the main factor determining seedling quality.

\section{Conclusions}

The substrates that include coconut fiber and decomposed yerba mate residues are viable for the production of yerba mate seedlings, providing seedling growth with quality similar to those produced in commercial substrates.

Total porosity, microporosity and $\mathrm{pH}$ of the substrates influence the growth of yerba mate seedlings.

\section{Acknoledgements}

We thank the Bitumirim Ind. Company of Yerba Mate Ltda. and José Amauri Padilha for their technical support.

\section{References}

Alvares, C.A., Stape, J.L., Sentelhas, P.C., Gonçalves, J.L.M., Sparovek, G. 2013. Köppen's climate classification map for Brazil. Meteorologische Zeitschrift 22: 71 1-728.

Barbosa, J.Z., Motta, A.C.V., Consalter, R., Poggere, G.C., Santin, D., Wendling, I. 2018. Plant growth, nutrients and potentially toxic elements in leaves of yerba mate clones in response to phosphorus in acid soils. Anais da Academia Brasileira de Ciências 90: 557-571

Barrett, G.E., Alexander, P.D., Robinson, J.S., Bragg, N. C. 2016. Achieving environmentally sustainable growing media for soilless plant cultivation systems - A review. Scientia Horticulturae 212: 220-234.

Binotto, A.F., Lúcio, A.D.L., Lopes, S.J. 2010. Correlations between growth variables and the Dickson Quality Index in forest seedlings. Cerne 16: 457-468.

Brasil. Ministério da Agricultura, Pecuária e Abastecimento (MAPA). Instrução Normativa SDA N 17. Diário Oficial da União - Seção 1, n 99, 24 de maio de 2007. Métodos Analíticos Oficiais para Análise de Substratos para Plantas e Condicionadores de Solo. Brasília.

Cuquel, F.L., Carvalho, M.L.M. de, Chamma, H.M.C.P. 1994. Avaliação de métodos de estratificação para a quebra de dormência de sementes de erva-mate. Scientia Agricola 51: 415-421.

Dartora, N., Souza, L.M. de, Paiva, S.M.M., Scoparo, C.T., lacomini, M., Gorin, P.A. K., Rattmann, Y.D., Sassaki, G.L. 2013. Rhamnogalacturonan from llex paraguariensis: A potential adjuvant in sepsis treatment. Carbohydrate Polymers 92: 1776-1782.
Dutra F. A., Araujo, M.M., Tabaldi, L.A., Rorato, D.G., Gomes, D.R., Turchetto, F. 2018. Optimization of water use in seedling production of arboreal species. Cerne 24: 201 208.

Fermino, M.H., Araujo, M.M., Aimi, S.C., Turchetto, F., Berghetti, A.L.P., Zavistanovicz, T.C., Mieth, P., Griebeler, A.M., Vilella, J.M.V. 2018. Reutilization of residues as components of substrate for the production of Eucalyptus grandis seedlings. Cerne 24: 80-89.

Fernandes, C.E., Kuhn, F., Scapinello, J., Lazarotto, M., Bohn, A., Boligon, A.A., Oliveira, J.V. 2016. Phyłochemical profile, antioxidant and hypolipemiant potential of llex paraguariensis fruit extracts. Industrial Crops and Products 81: 139-146.

Fowler, J.A.P., Sturion, J.A. 2000. Aspectos da formação do fruto e da semente na germinação da erva-mate. Embrapa Florestas, Colombo, Brazil. 5 p. (Embrapa Florestas. Comunicado Técnico, 45)

Gomes, J.M., Couto, L., Leite, H.G., Xavier, A., Garcia, S.L.R. 2002. Parâmetros morfológicos na avaliação da qualidade de mudas de Eucalyptus grandis. Árvore 26: 655-664.

Gonçalves, J.L.M., Santerelli, E.G., Neto, S.P.M., Manara, M.P. 2000. Produção de mudas de espécies nativas: substrato, nutrição, sombreamento e fertilização. In: Gonçalves, J.L.M., Benedetti, V. (eds.). Nutrição e fertilização florestal. IPEF, Piracicaba, Brazil. p. 309 - 350.

Holowaty, S.A., Trela, V., Thea, A.E., Scipioni, G.P., Schmalko, M.E. 2016. Yerba Maté (llex paraguariensis St. Hil.): chemical and physical changes under different aging conditions. Journal of Food Process Engineering 39: 19-30.

Kratz, D., Nogueira, A.C., Wendling, I., Mellek, J.E. 2017. Physic-chemical properties and substrate formulation for Eucalyptus seedlings production. Scientia Forestalis 45: 63-76.

Kratz, D., Wendling, I., Nogueira, A.C., Souza, P.V.D. 2013. Substratos renováveis na produção de mudas de Eucalyptus benthamii. Ciência Florestal 23: 607-621.

Kratz, D., Wendling, I., Stuepp, C.A., Fragoso, R.O. 2016. Ranking of substrates based on Piptadenia gonoacantha morphological parameters. Bosque 37: 265-271.

Pascual, J.A., Ceglie, F., Tuzel, Y., Koller, M., Koren, A., Hitchings, R., Tittarello, F. 2018. Organic substrate for transplant production in organic nurseries. A review. Agronomy for Sustainable Development 38: 35.

R CORE TEAM. R: A Language and Environment for Statistical Computing. R Foundation for Statistical Computing, Viena. 2019.

Raviv, M. 2013. Composts in growing media: what's new and what's next? Acta Horticulturae 982: 39-52.

Reissmann, C.B., Radomski, M.I., Quadros, R.M.B. 1999. Chemical composition of Ilex paraguariensis St. Hil. Under different management conditions in seven localities of 
Paraná state. Brazilian Archives of Biology and Technology 42: 187-194.

Silva, R.B.G., Simões, D., Silva, M.R. 2012. Qualidade de mudas clonais de Eucalyptus urophylla $\times$ E. grandis em função do substrato. Revista Brasileira de Engenharia Agrícola e Ambiental 16: 297-302.

Simões, D., Silva, R.B. G., Silva, M.R. 2012. Composição do substrato sobre o desenvolvimento, qualidade e custo de produção de mudas de Eucalyptus grandis Hill. Ex Maiden x Eucalyptus urophylla S. T. Blake. Ciência Florestal 22: 91-100.

Suguino, E., Martins, A.N., Perdoná, M.J., Narita, N., Minami, K. 2013. Efeito da porosidade do substrato casca de pinus na produção de mudas de pitangueira e uvaieira. Nucleus 10: 643-648.

Trigueiro, R.M., Guerrini, I.A. 2014. Utilização de lodo de esgoto na produção de mudas de aroeira pimenteira. Revista Árvore 38: 657-665.

Wendling, I., Delgado, M.E. 2008. Produção de mudas de araucária em tubetes. Embrapa Florestas, Colombo, Brazil. 8 p. (Embrapa Florestas. Comunicado técnico, 201).

Wendling, I., Guastala, D., Dedecek, R. 2007. Características físicas e químicas de substratos para produção de mudas de llex paraguariensis St. Hil. Revista Árvore 31: 209-220.

Conflict of Interest Statement: The authors declare that the research was conducted in the absence of any commercial or financial relationships that could be construed as a potential conflict of interest.

All the contents of this journal, except where otherwise noted, is licensed under a Creative Commons Attribution License attribuition-type BY. 